\title{
QUALITY OF LIFE AND LIVING CONDITIONS FROM THE VIEWPOINT OF RESIDENTS IN A SENIORS CONDOMINIUM
}

\author{
Elen Ferraz TESTON ${ }^{a}$, Sonia Silva MARCON ${ }^{b}$
}

\section{ABSTRACT}

The aim of the study was to understand how residents of a condominium Aging realize the quality and conditions of life in this new housing modality. This is an exploratory qualitative study of 20 elderly residents of the condominium Maringá . Data were collected in February 2012 in the household were semistructured and subjected to content analysis interviews. The results indicate the factors valued by the elderly in their perception of quality of life such as independence, autonomy, having an occupation, developing leisure and acceptance of the aging process activities. Also valued the structure and characteristics of this housing method due to the possibility of social interaction. We conclude that the identification of these aspects allows the planning of strategies for integrated care for the elderly and it is suggested that nurses recognize and value the aspects highlighted in the planning of care with elderly people in general.

Descriptors: Housing for the elderly. Quality of life. Health of the elderly. Nursing.

\section{RESUMO}

O objetivo do estudo foi conhecer como os residentes de um "condomínio do idoso" percebem a qualidade e condições de vida nessa nova modalidade habitacional. Trata-se de um estudo exploratório, de abordagem qualitativa, realizado com 20 residentes do Condomínio do Idoso de Maringá. Os dados foram coletados em fevereiro de 2012 no próprio domicílio, mediante entrevistas semiestruturadas, e submetidos à análise de conteúdo. Os resultados apontam os fatores valorizados pelos idosos em sua percepção de qualidade de vida, tais como independência, autonomia, ter uma ocupação, desenvolver atividades de lazer, bem como aceitação do processo de envelhecimento. Valorizam-se também a estrutura e as características dessa modalidade habitacional, devido à possibilidade de convívio social. Conclui-se que a identificação desses aspectos permite o planejamento de estratégias para o cuidado integral do idoso, e sugere-se que os enfermeiros reconheçam e valorizem os aspectos apontados no planejamento de ações de cuidado de idosos em geral.

Descritores: Habitação para idosos. Qualidade de vida. Saúde do idoso. Enfermagem.

Título: Qualidade e condições de vida sob a ótica dos residentes de um condomínio do idoso.

\section{RESUMEN}

El objetivo del estudio era entender cómo los residentes de un Envejecimiento condominio se dan cuenta de la calidad y condiciones de vida en esta nueva modalidad de vivienda. Se trata de un estudio cualitativo exploratorio de 20 ancianos residentes del condominio Maringá. Los datos fueron recogidos en febrero de 2012 en el hogar fueron semiestructuradas y sometidos a análisis de contenido de las entrevistas. Los resultados indican los factores valorados por las personas mayores en su percepción de la calidad de vida, tales como la independencia, la autonomía, tener una ocupación, el desarrollo del ocio y la aceptación de las actividades del proceso de envejecimiento. También valoró la estructura y las características de este método de viviendas debido a la posibilidad de interacción social. Llegamos a la conclusión de que la identificación de estos aspectos permite la planificación de estrategias para la atención integral a las personas mayores y se sugiere que las enfermeras reconocen y valoran los aspectos que se resaltan en la planificación de la atención a las personas mayores en general.

Descriptores: Vivienda para ancianos. Calidad de vida. Salud del anciano. Enfermería.

Título: La calidad de vida bajo la óptica de los residentes de un condominio del anciano.

a Nurse belonging to the Family Health Strategy in the town of Jandaia do Sul. Studying for a doctorate at the State University of Maringá (UEM), Paraná, Brazil.

b Nurse. Doctor of Nursing Philosophy. Professor of Undergraduate and Graduate courses in Nursing at the State University of Maringá (UEM),Paraná, Brazil. Coordinator of the Center for Study, Research, Assistance and Support of the Family - NEPAAF. 


\section{INTRODUCTION}

The Seniors Statute, sanctioned in 2003, has the intention of guaranteeing rights for seniors and incorporating the focus of the integrality of care for the elderly. Chapter IX of this statues deals with the issue of Accommodation, and explains that in public residence programs seniors are a priority in the acquisition of property for habitation, with $3 \%$ of residential units reserved for them ${ }^{(1)}$. In this context, Seniors Condominiums have arisen as a new accommodation modality directed exclusively at the elderly on low income, and constitutes a strategy to ensure the right to accommodation, especially for those that live in precarious conditions ${ }^{(2-3)}$.

This is still a recent housing modality in Brazil $^{(2)}$, and as far as we know is only present in a few locations: Uberlândia (Minas Gerais), Nova Andradina (MS), Niterói (Rio de Janeiro), Jundiaí (São Paulo), João Pessoa (Paraíba). In the State of Paraná they are present in Francisco Beltrão, Maringá and Guarapuava, while internationally, for example in North America, Australia and New Zealand, this housing modality has existed for more than 60 years. It is estimated that $5 \%$ of elderly Americans live in these condominiums ${ }^{(4)}$.

In Brazil, unlike what happens in retirement homes and shelters, the inhabitants of this housing modality are independent, pay rent (symbolic amount) for their accommodation and have the autonomy to come and go as they please, as well as deciding on the organization of the condominium collectively ${ }^{(3)}$. In relation to the physical area, at the same time that seniors can maintain their individuality, given that the accommodation is individual, they can also take part in social activities, as there is a common space for all residents allowing the development of recreational and group activities.

In addition to provide the right to dignified housing, the Seniors Condominiums valorize the maintenance of the Quality of Life (QOL) of their residents ${ }^{(2)}$, a factor which is an important parameter in the evaluation of public policies. However, the concept of QOL is not easily understood and involves the perception of the individual about their position in life, considering individual aspects and the cultural, social and environmental context of which they are a part ${ }^{(5)}$.

After recognizing the existence of these Seniors Condominiums various personal reflections and concerns arise in relation to the experiences of seniors in this new housing modality. Therefore, this study aims to respond to the following question: what is the perception of elderly residents in this new housing modality in relation to QOL, given that this is one of the objectives of this housing policy? To respond to this, the objective of this study was defined as understanding how residents in a Seniors Condominium perceive quality of life and living conditions in this new housing modality.

The relevance of the study is in the location where it was conducted, given that Senior Condominiums constitute a recent housing modality in Brazil ${ }^{(2)}$ and therefore there is a lack of studies whose results could favor an evaluation of this housing policy in relation to fulfilling one of its purposes, which is to improve and maintain the QOL of seniors.

This study intends to contribute to the understanding of gerontological nursing, favoring the planning and implementation of improvements in the care given to the elderly, given that QOL influences their health conditions, autonomy and independence.

\section{METHODOLOGY}

Exploratory study with a qualitative approach, derived from an overriding study ${ }^{(6)}$ about the living and health conditions of elderly residents in the first and only Seniors Condominium in the municipality of Maringá, Paraná, which was established in August 2010 and counts on 40 dwellings constituted by a living room, kitchen, bedroom and bathroom. It has a community garden, Seniors Gym, and a square with benches and tables.

The accommodation is loaned for use, and is only acquired after registration with the $\mathrm{Mu}-$ nicipality's Housing Program and selection by the Department of Social Assistance. The dwellings are destined for the elderly with social vulnerability, that live alone or with a companion and present functional independence.

The data was collected in February 2012 using a semi-structured interview carried out at the dwellings. The interviews, after consent, were recovered and had an average duration of 20 minutes. A semistructured script was used composed of two parts. The first characterizing the seniors using section I (composed of 10 questions) from the BOAS (BRAZIL 
OLD AGE SCHEDULE) translated and validated in Brazil $^{(7)}$, which is constituted of nine sections with the objective of collecting information relating to different areas of life, such as characteristics, needs and specific problems in the elderly population ${ }^{(7)}$.

The second part is constituted of three guiding questions elaborated by the actual authors based on the objectives of the study: 1 . What does having QOL mean to you?; 2. How would you evaluate your living conditions before and after moving to the condominium?; 3. Has there been any change in your living conditions after moving here? Talk about this.

20 of the 50 seniors resident at the condominium participated in the study. No other criteria other than living at the condominium were adopted for inclusion in or exclusion from the study. The participants therefore were the first 20 seniors approached, given that the information collected up to then, despite being repeated, was sufficient to respond to the objectives of the study.

For analysis of the data, the interviews were transcribed in full and then submitted to thematic content analysis. The reanalysis, exploration of material, treatment of the results and interpretation phases were followed. In the first phase the speech was read, aimed at studying relevant points for the objective of the study. In the exploration of the material, the data was coded, i.e. the raw data was systematically transformed and groups into units. In the treatment of the results categorization was carried out, consisting of the classification of elements according to similarity or difference, with subsequent regrouping in accordance with common characteristics ${ }^{(8)}$.

The study was approved by the Permanent Committee for Ethics in Research with Human Beings at the State University of Maringá (Report $\mathrm{n}^{\circ}$. 709/2011). All of the participants signed two copies of the Statement of Free and Clarified Consent and to preserve their identities, their reports are identified with the letter E following by an identification number, followed by $\mathrm{F}$ or $\mathrm{M}$ to indicate if they are male or female, followed by their age.

\section{RESULTS}

12 of the 20 seniors interviewed were women, 11 lived alone, 13 had children and 13 identified as Roman Catholic. The age varied between 62 and 85 years, with an average of 72 years, 13 had up to
4 years of education and five were illiterate, and 15 were receiving a minimum wage as a pension.

The analysis of the data enabled the identification of two categories that will be described below.

\section{Personal factors involved in the concept of QOL}

The reports show the existence of different factors considered as important for maintaining QOL, such as good health:

For a person to have good quality of life they have to do everything to benefit their body and health, because those who have good health, have everything (E5, F, 68 years).

We always need to look after our health and our image... we have to be like that, to keep a good image, take care of the body, health, the mind, and then QOL will be a consequence (E14, M, 85 years).

Having a good life means having health, because those who have good health, have everything (E7,M, 72 years).

Another factor identified relates to acceptance of the aging process and consequent recognition of the positive points of this stage of life:

For you to have QOL you can't keep living in the past because the present is also full of good things [...] (E2O, $F, 83$ years).

[…] it doesn't matter your age, if you're 20,30,40,50 or 80 years old, what's important is to be happy at your current age and know that today will never come back, and everyone is going to get old. There are people that get fixated on this and this interferes with their QOL (E12, M, 69 years).

Some seniors demonstrated in their reports that for them QOL is also related to presenting in day-to-day activities:

For me, QOL means being able to do things for myself, without having to explain or wait for someone else (E8, F, 73 years);

Aah, to do my jobs, to go shopping the way I want. Right? To not need to keep asking to do things (E3,F,65 years)

QOL is a way of living more peacefully and independently, right? To not need to keep asking to do things 
in other people's homes, it means coming and going whenever you want (E1,M, 67 years)

Lastly, two of the participants referred to $\mathrm{QOL}$ as the power to participate in different recreational activities:

Having QOL means living well, being able to do what you like, working, not worrying about things pointlessly, swimming, going to the seniors groups. That's all QOL, because we talk, have fun, have a chat (E1 8, F, 73 years).

QOL means doing what we like, getting involved in activities, walking around, getting to know new things (E11,F,69 years).

\section{Characteristics of the Condominium perceived as positive on quality of life and living conditions}

Some of the conditions offered by the housing policy were cited as influence QOL, including the accommodation conditions and physical structure of the condominium:

The condominium offers good QOL for us seniors because I, for example, used to live in a room and the bathroom was shared, here everything I have a better, organized house (E13, F, 66 years).

QOL depends a lot on where you live and the conditions too. Where I used to live it was just a small room with a bed and wardrobe. It was just a bedroom. The bathroom was shared. The placed was like a hostel, that had a place to sleep, a lot of people that didn't have (financial) conditions stayed there. My QOL improved 100\% after I came to live here (E9, M, 70 years).

The interviewees also highlighted the fact that paying an accessible amount for accommodation was a positive factor, as it enabled access to other goods:

Another thing that improved a lot in my QOL is that living here, with the money I saved on rent I've been able to buy furniture for my home, I bought a double bed too (E2, F, 70 years).

I think that that what improved most in my life is that living here, the money we spent a lot on rent before now goes a little further, so we can buy things we need, a sofa, a cooker, something different to eat, whatever we want (E16, M, 78 years).
It's almost two years that I've been living here and up to now the amount we pay is almost nothing. This has improved my life, because living here makes us calmer about the other bills we need to pay (E19,F, 66 years).

The possibility of establishing longer lasting social relationships and mutual support was also valued and stated as influencing QOL:

My life is very good. Beforehand I was alone a lot... after moving here there is always someone in the square or on the patio, so there's no lack of company. I even got a girlfriend (laughs), something I thought would never happen again. And I tell her that alone is good, but together its better (laughs) (E1O, M, 71 years).

The neighborhood is good and well united, it's a family already. At Christmas we get together over there and have lunch for those who don't have families. These things make us happier and have more desire to live (E4, F, 62 years).

The activities undertaken by interns and the trips organized by the Department of Social Assistance complete the list of actors considered as influencing QOL:

Life here is so good. Sometimes there's a van for us to go on a trip, we've been fishing, the theater, bowling, and even to the cinema. This makes us all happier. (E6, $M, 77$ years).

Every Monday and Wednesday the physiotherapy students come to exercise with use. Beforehand I used to fall all the time and later I started doing gymnastics and exercises, and it seems that I'm stronger, I'm on my feet more (laughs).(E1O, M, 71 years).

The trips do a lot of good for our emotional state and even our health. After I moved here I got to know everything, bowling, cinema, I've even been to the water park (laughs)... (E1 5,F,69 years)

Lastly, despite no literacy activities being offered by the condominium, this was also an aspect valued by the seniors:

Today I can say that my QOL is much better. After moving to the condominium I've start studying again (laughs). Knowing how to read and life is everything in a person's life. Previously I didn't even know how to take the bus alone, I used to go to the supermarket and didn't know the price of things. Now everything is much easier. (E17, F, 81 years). 


\section{DISCUSSION}

QOL is related to numerous factors: the context in which the individual is included, the objective and subjective parameters, and personal perception ${ }^{(9-10)}$. When defining QOL, seniors value aspects related to health, but also demonstrate that it is not just understood by them as the absence of diseases. This finding demarcates the distancing of QOL from biological reductionism, enabling direct interventions on the living and health conditions of the elderly, as indicated in the study conducted with seniors in a health district in Porto Alegre, RS, Brazil ${ }^{(11)}$.

Statements E8 to E3 reiterate the relationship between QOL and the autonomy to make decisions, corroborating the findings of the study conducted on seniors in the interior of Rio Grande do Sul, Brazil, which indicated autonomy as a fundamental factor in QOL and preservation of dignity, given that making decisions about their lives was associated with living well ${ }^{(12)}$.

Given the importance of preserving autonomy for QOL in seniors, it is necessary to carry out planning of strategies aimed at its maintenance, such as the development of self-care actions, health education and the incentive to practice regular physical exercise as, if the senor becomes dependent on care, their QOL will be compromised, as well as no longer being classified within the requirements to reside in this condominium.

The seniors being studied also referenced the importance of recreational and occupational activities for maintaining QOL. A study of 2143 seniors resident in the urban zone of Uberaba, MG, Brazil indicated that senior involvement in recreational activities, in accordance with their interest and limitations, was a positive influence on $\mathrm{QOL}^{(19)}$. This demonstrates that it is necessary for health professionals to incentivize participation by seniors in various recreational activities - walking, group living etc.

The need to recognize the aging process and accept it as emphasized in statements E12 and E20 leads to reflection about the fact that aging implies constant change, knowing how to deal with loss, seeking new acquisitions during the entire process in order to live through it naturally and healthily ${ }^{(14)}$.

Therefore, in planning the implementation of healthcare for the elderly, health professionals, especially nurses, should address and discuss physi- ological changes inherent in the ageing process so that they can recognize that this phase of life also has positive aspects.

It was noted in the statements that the conditions and opportunities offered by the housing policy were evaluated as influencing QOL. These results corroborate those from an international study $^{(15)}$, which indicated that residents in the condominium were completely satisfied with the housing conditions, especially those related to security and privacy.

In a European study conducted in the United Kingdom $^{(4)}$, it was noted that this type of housing modality provided a positive lifestyle, reinforcing the concept of "aging with quality". It is important to reiterate that QOL if old age depends on many elements in constant interaction throughout life. This, aging satisfactorily depends on the balance between the limits imposed by the years lived and the capacities/potential of the individual. Such a relationship enables seniors to deal better with the losses characteristic of aging ${ }^{(10)}$.

In turn, socializing is fundamental for people to live better at any time in their lives. The "seniors programs", according to the elderly themselves, are very important tools for better QOL from a social point of view, because they offer different proposals for recreation and occupying spare time. They are spaces in which socialization and interaction with and between seniors permit symbolic ties of identification to be built and where it is possible to share and negotiate the meaning of old age, build new models and paradigms about ageing and build new social identities ${ }^{(16)}$.

One of the factors resulting from socialization provided by the experience of living in a Seniors Condominium that affects the QOL of residents is the opportunity for social interaction between seniors, which corroborates the results of a study in Europe, conducted in England, which found that social interaction was the most influential factor on $\mathrm{QOL}^{(4)}$, as socialization between residents promotes friendship and companionship, reducing feelings of loneliness.

The physical area of the condominium should be structured and built in accordance with the specificities and needs of the elderly ${ }^{(2)}$, and this characteristics was also referenced by residents as a factor influencing the maintenance of QOL. This locations generally present a planned physical space appropriate for seniors, contributing to 
maintaining their autonomy and QOL, as well as favoring a positive lifestyle by enabling, concomitantly, opportunities for companionship, privacy and independence ${ }^{(2)}$. Thus, it is possible to infer that the physical environment of the condominium favors the positive evaluation of the seniors under study in relation to QOL. E9 to E13, for example, show the difficult social and housing contexts in which they lived, justifying the association between improved QOL and their current accommodation.

The seniors participate in cultural and social activities outside of the condominium planned by the Department of Social Assistance, such as trips, cinema, bolding and fishing, in addition to the activities undertaken weekly within the condominium itself, such as exercises promoted by physiotherapy interns from a university in the town, and the stretching offered by a hired physical trainer. All of these activities are recognized by the seniors as boosting QOL, corroborating a review of the literature review study ${ }^{(17)}$. Therefore, it is necessary in addition to offering these activities, to have a permanent incentive for seniors to participate, aimed at maintaining their functional capacity and physical aptitude, and favoring their self-esteem.

Illiteracy among the elderly is still a reality in developing countries ${ }^{(17)}$. The importance that literacy represents in the QOL of seniors can be inferred from statement E17, presenting itself as indispensable for conducting basic day-to-day activities, and this is represented by the desire and right to change over time, regardless of age. Despite literacy activities not being offered at the condominium, it is believed that the socialization between residents was sufficient to stimulate this initiative. Research conducted with seniors frequenting socio-educational programs maintained by a higher education institution revealed the value conferred to education and the recognition of its role as a resource facilitating the development process. Education is a right and as such should be guaranteed for the elderly as an unquestionable requisite for $\mathrm{QOL}^{(18)}$. Furthermore, a higher level of education helps seniors to learn more information related to their own living and health conditions.

\section{FINAL CONSIDERATIONS}

Based on the results obtained in the investigation, the seniors who participated considered QOL as being health, independent, autonomous, being occupied and having recreation, as well as the need of accepting the aging process. They also referred to some of the characteristics of the new housing modality as contributing to QOL - the physical structure, social interaction with other residents, the numerous activities offered and opportunities for literacy.

It was verified, therefore, that seniors living in this accommodation consider there to be numerous positive aspects that contribute to QOL. The identification of these aspects permits the planning of strategies in the integral care of seniors in relation to promoting and maintaining QOL, given that this is a facto that directly influences longevity.

Given this, it is suggested that nurses should recognize and value the aspects identified by the seniors and invest in actions that can contributed to different activities, with the objective of establishing and maintaining social relationships, as well as access to opportunities not experienced before.

The fact that the information was obtained from the elderly residents in a single Seniors Condominium could be considered as a limitation on this study. New studies are suggested in other condominiums in order to compare and/or confirm the results found here in relation to the positive impact of this housing modality on the QOL of seniors.

\section{REFERENCES}

1 Brasil. Lei no 10.741, de $1^{\circ}$ de outubro de 2003. Dispõe sobre o Estatuto do Idoso e dá outras providências. Diário Oficial [da] União, Brasília, DF, Seção 1, 3 out. 2003.

2 Teston EF, Rossi RM, Marcon SS. Utilização de servicos de saúde por residentes em um condomínio exclusivo para idosos. Rev Esc Enferm USP. 2013;47(5):1125-32.

3 Deus SIA. Um modelo de moradia para idosos: o caso da Vila dos Idosos do Pari-São Paulo (SP). Cad Tem Kairós Gerontol [Internet]. 2010 [citado 2012 ago. 25];8:195-213. Available in: http://revistas.pucsp.br/ index.php/kairos/article/view/6922/5014

4 Evans S. That lot up there and us down here: social interaction and a sense of community in a mixed tenure UK retirement village. Ageing Soc. 2009;29(1):199-216. 
5 The WHOQOL Group. The world Health Organization quality of life assessment: position paper from the World Health Organization. Soc Sci Med. 1995;41(10): 1403-9.

6 Teston EF. Condomínio para Idosos: implicações para a saúde e o cuidado de enfermagem nessa nova modalidade habitacional [dissertação]. Maringá (PR): Universidade Estadual de Maringá, 2012.

7 Veras R, Dutra S. Perfil do idoso brasileiro: questionário BOAS. Rio de Janeiro: UERJ, UnATI; 2008.

8 Bardin L. Análise de conteúdo. Lisboa: Edições 70; 2008.

9 Maués CR, Paschoal SMP, Jaluul O, França CC, Jacob Filho W. Avaliação da qualidade de vida: comparação entre idosos jovens e muito idosos. Med. São Paulo, 2010 set-out;8(5):405-10.

10 Faller JW, Melo WA, Versa GLGS, Marcon SS. Qualidade de vida dos idosos cadastrados na estratégia saúde da família de Foz do Iguaçu-PR. Esc Anna Nery. 2010;14(4):803-10.

11 Paskulin LMG, Cûrdova FP, Costa FM, Vianna LAC. Percepção de pessoas idosas sobre qualidade de vida. Acta Paul Enferm. 2010; 23(1):101-7.

12 Flores GC, Borges ZN, Budó MLD, Mattioni FC. Cuidado intergeracional com o idoso: autonomia do idoso e presença do cuidador. Rev Gaúcha Enferm. 2010;31(3):467-74.

13 Tavares, DMS, Côrtes RM, Dias FA. Qualidade de vida de idosos com diabetes mellitus. Cienc Cuid Saúde. $2011 \mathrm{abr} / \mathrm{jun} ; 10(2)$ :290-7.

14 Souza RF, Matias HA, Bretãs ACP. Reflexões sobre envelhecimento e trabalho. Cienc. Saúde Coletiva. 2010;15(6):2835-43.

15 Bernard M, Bartlam B, Sim J, Biggs S. Housing and care for older people: life in an English purpose-built retirement village. Ageing Soc. 2007; 27(4):555-78.

16 Rizolli D, Surdi AC. Percepção de idosos sobre grupos de terceira idade. Rev Bras Geriatr Gerontol. 2010;13(2):225-33.

17 Vidmar MF, Potulski AP, Sachetti A, Silveira MM, Wibelinger LM. Atividade física e qualidade de vida em idosos. Saúde Pesqui. 2011;4(3):417-24.

18 Silva LRMS, Bacelar ATRFD. O que pensam os idosos frequentadores do Centro de Atenção Integral a saúde do idoso (CAISI) em São Luis (MA) sobre o lazer. Revista Portal de Divulgação [Internet]. 2011;1(6):21-5. Available in: http://portaldoenvelhecimento.org.br/revista-nova/index.php/revistaportal/article/view/98/98

\author{
Author's address / Endereço do autor / \\ Dirección del autor \\ Elen Ferraz Teston \\ Rua Luiz Vignoli, 597, ap. 3 \\ 86900-000, Jandaia do Sul, PR \\ E-mail: elen-1208@hotmail.com
}

Received: 31.01.2013

Approved: 20.01.2014 